\title{
Mass occurrence and habitat selection of Common Redpolls (Carduelis flammea) after a large seed crop year: snow-covered ground facilitates food access
}

\author{
Svein Dale ${ }^{1}[0$
}

Received: 15 December 2020 / Revised: 15 May 2021 / Accepted: 1 July 2021 / Published online: 11 July 2021

(c) The Author(s) 2021

\begin{abstract}
In boreal forests, food supplies typically have cyclic variations, and many species here fluctuate in numbers from year to year. One group of species showing large variations in population size is birds specialized on seeds from masting trees. Here, I analyze spatial patterns of a mass occurrence and habitat selection of the Common Redpoll (Carduelis flammea) during the breeding season in southeastern Norway in 2020 after a year with large seed crops from Norway Spruce (Picea abies) and Downy Birch (Betula pubescens). I found that Common Redpoll numbers increased with elevation and towards the northwest. Numbers were also strongly and positively correlated with snow depth in early April when snow was present mainly above $400 \mathrm{~m}$ elevation. Sites with snow cover in early April (30\% of all sites) held $96.4 \%$ of all individuals recorded. Field observations indicated that Common Redpolls foraged extensively for spruce seeds on the snow until the end of May when young were independent. I suggest that the mass occurrence was due to a unique combination of exceptionally large seed crops of two tree species coinciding in the same year. The masting produced large amounts of food both for overwintering (birch seeds) and for breeding (spruce seeds), and during the breeding season snow cover facilitated access to food resources. Dependency of Common Redpolls on snow cover suggests that climate change may negatively impact some seed-eaters in boreal regions. On the other hand, higher temperatures may induce more frequent masting which may be beneficial for seed-eaters. Thus, climate change is likely to lead to complex ecosystem changes in areas where snow cover may disappear.
\end{abstract}

Keywords Betula pubescens $\cdot$ Climate change $\cdot$ Irruptive species $\cdot$ Picea abies $\cdot$ Population cycles $\cdot$ Snow ecology

\section{Zusammenfassung}

Massenhaftes Auftreten und Habitatselektion des Taigabirkenzeisigs (Carduelis flammea) nach einem Mastjahr: schneebedeckter Boden erleichtert den Zugang zur Nahrung

In borealen Nadelwäldern unterliegt das Nahrungsangebot normalerweise periodischen Schwankungen, und für viele der dort vorkommenden Arten schwanken die Bestandszahlen von Jahr zu Jahr. Eine Artengruppe, die starke Bestandsschwankungen zeigt, sind Vögel, die auf Samen von Bäumen mit zyklischer Fruchtbildung spezialisiert sind. Hier analysiere ich die räumlichen Muster eines massenhaften Auftretens des Taigabirkenzeisigs (Carduelis flammea) und seiner Habitatselektion im Südösten Norwegens während der Brutsaison 2020, die auf ein Mastjahr der Gemeinen Fichte (Picea abies) und Moor-Birke (Betula pubescens) folgte. Ich fand heraus, dass die Zahl der Taigabirkenzeisige mit steigender Höhenlage und in Richtung Nordwesten zunahm. Die Zahlen zeigten zudem eine starke positive Korrelation mit der Schneehöhe Anfang April, als Schnee hauptsächlich auf Höhen über 400 m vorkam. 96.4\% aller nachgewiesenen Individuen fanden sich an Standorten, die Anfang April von Schnee bedeckt waren (insgesamt 30\% aller Standorte). Feldbeobachtungen zeigten, dass Taigabirkenzeisige

Communicated by T. Gottschalk.

Svein Dale

svein.dale@nmbu.no

1 Faculty of Environmental Sciences and Natural Resource

Management, Norwegian University of Life Sciences,

P.O.Box 5003, 1432 Ås, Norway 
weitgehend auf dem Schnee nach Fichtensamen suchten, und zwar bis Ende Mai, als die Jungen unabhängig wurden. Ich schlage vor, dass das massenhafte Auftreten auf eine einzigartige Kombination der Mastjahre zweier Baumarten, die zufällig im selben Jahr auftraten, zurückzuführen war. Die Mast produzierte große Nahrungsmengen sowohl für den Winter (Birkensamen) als auch für die Brutsaison (Fichtensamen), und während der Brutsaison erleichterte die Schneedecke den Zugang zu Nahrungsressourcen. Die Abhängigkeit der Taigabirkenzeisige von der Schneedecke deutet darauf hin, dass der Klimawandel einige Samenfresser in borealen Gebieten negativ beeinträchtigen könnte. Andererseits könnten höhere Temperaturen eine Samenmast häufiger auslösen, was für Samenfresser von Vorteil sein könnte. Daher führt der Klimawandel in Gebieten, wo die Schneedecke verschwinden könnte, wahrscheinlich zu komplexen Ökosystemveränderungen.

\section{Introduction}

Boreal forests are characterized by cyclic resource pulses that generate large year-to-year variations in numbers of, for example, rodent-eating predators and birds specializing on seeds from masting trees (Newton 1998; Cheveau et al. 2004; Sundell et al. 2004). During peak resource years, the number of individuals breeding, reproductive success and survival is high leading to a large population size (e.g., Newton 1998). Subsequent decline in food availability often causes emigration and irruption to areas outside the regular distribution range (Koenig and Knops 2001; Newton 2006).

Exploitation of resource pulses depends on the accessibility of the food. For a variety of reasons access to abundant resources may not always be straightforward. Seeds from coniferous trees may be well protected inside cones for months and only a few species may be able to gain access before cones open and seeds are shed. For example, crossbills (Loxia spp.) have a specialized bill to pry cone shells open and reach the seeds (Newton 1972; Cramp and Perrins 1994), and can exploit seeds before other species.

Snow cover may influence access to food or foraging efficiency. Snow may provide a protective cover for rodents so that rodent-eating predators may experience reduced hunting success and have to change hunting tactics, habitat and winter distribution (Sonerud 1986; Nybo and Sonerud 1990; Jacobsen and Sonerud 1993; Bilodeau et al. 2013). Prey may be difficult to detect if they are camouflaged against the snow, while on the other hand reduced snow cover may make prey more vulnerable to predation (Melin et al. 2020).

For trees that shed their seeds before winter, snowfalls may cover seeds on the ground and thereby reduce access to food for ground-feeding seed-eaters. Bramblings (Fringilla montifringilla) consume seeds of European Beech (Fagus sylvatica) that are on the ground during winter, and snow cover forces them to move towards the south or southwest (Jenni 1987). Thus, snow cover is in many cases a problem for consumer species exploiting resources on the ground (see also Callaghan 2011a; Boelman et al. 2019; Slatyer and Arnold 2020).

On the other hand, snow has been found to be beneficial for some mountain birds that forage for insects and seeds trapped on snow patches during the summer season (Antor
1995; Rosvold 2016; Resano-Mayor et al. 2019). Regarding seed-eaters in forested areas, the benefit of snow cover depends on when masting trees drop their seeds, and snow cover may turn from a problem (e.g., Jenni 1987) to an advantage. For example, the cone shells of Norway Spruce (Picea abies; hereafter spruce) usually open during late winter, and seeds are shed when the ground is snow-covered. Seeds on the snow are easy to see (Fig. 1), and snow cover may therefore facilitate access to abundant food resources for seed-eaters (Fig. 2). In particular during late winter, when there are few new snowfalls covering seeds on the snow, but rather melting that exposes seeds buried in the snow, snow-covered ground may provide a rich foraging opportunity. However, there are few previous studies of the importance of snow cover for seed-eaters in boreal forests (but see Hogstad 1996).

The Common Redpoll (Carduelis flammea; hereafter redpoll) is considered a specialist on seeds of Downy Birch (Betula pubescens; hereafter birch), and peak breeding years often follow peaks in seed crop of birch (Haftorn 1971, 1998; Cramp and Perrins 1994; Hogstad 1996). However, the redpoll may also feed heavily on seeds from spruce when they are available (Haftorn 1971; Haldås 1971; Cramp and Perrins 1994; Lifjeld and Bjerke 1996). The breeding distribution of redpolls, in particular the nominate form C. $f$. flammea, is mainly in the boreal zone (Haftorn 1971; Cramp and Perrins 1994) in areas that typically have snow cover through the winter, and often well into the start of the breeding season.

Here, I investigate the hypothesis that snow cover facilitates food access for redpolls during the breeding season. Data were collected during a mass occurrence of redpolls during the breeding season in southeastern Norway after a year with large seed crops from spruce and birch. The mass occurrence provided a rich source of redpoll abundance data in an area where snow conditions are variable, depending on elevation, and where redpolls in normal years are scarce. In the normal breeding areas at high elevation in subalpine birch forest, snow conditions are less variable with most areas having snow cover at the start of the breeding season. I predicted that distribution and abundance of redpolls would be affected by snow cover, specifically that redpolls should settle in areas with snow 
Fig. 1 Seeds of Norway Spruce (Picea abies) on the snow at Marifjell (650 m a.s.l.), Nannestad municipality, Viken county, Norway on 31 March 2020. Photo: Svein Dale

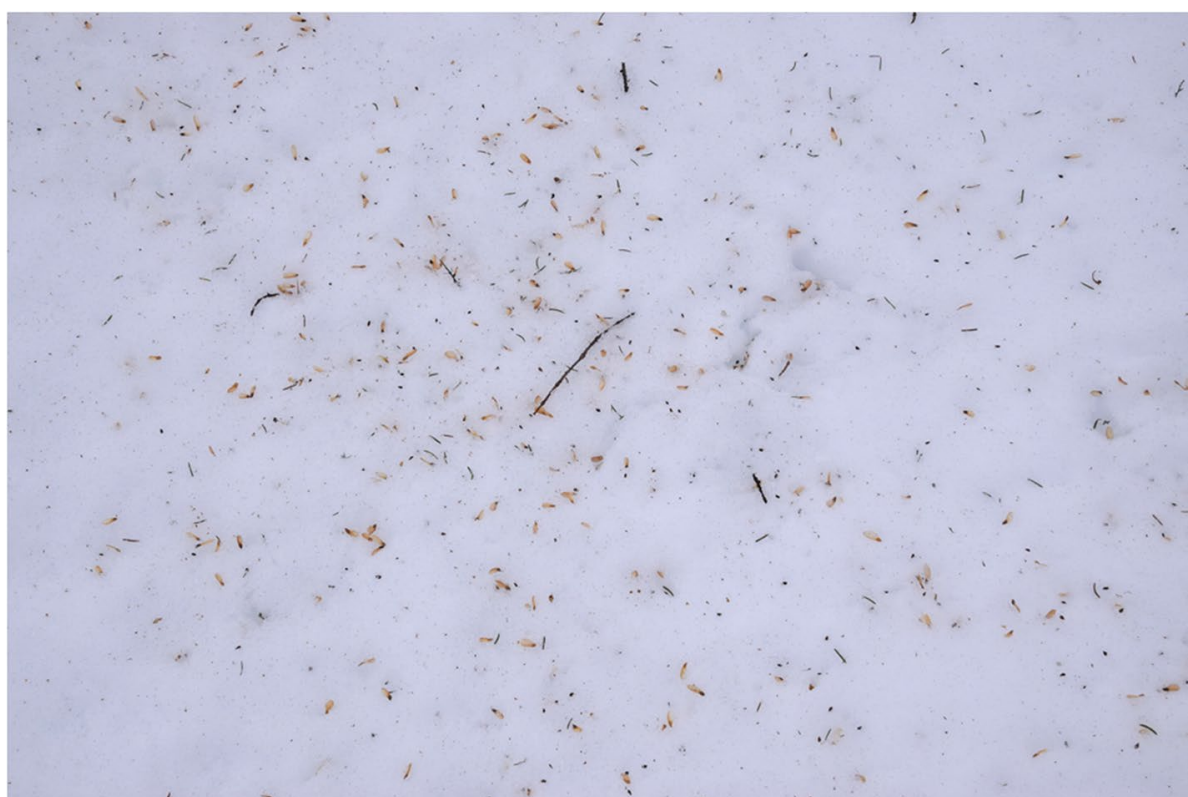

Fig. 2 Common Redpolls (Carduelis flammea) feeding on seeds of Norway Spruce (Picea abies) on the snow in a mixed subalpine birch forest at Lyseren (975 m a.s.1.), Nesbyen municipality, Viken county, Norway (outside the study area) on 8 February 2020. The redpolls are the ca. 100 small dots on the snow between the trees, shown in detail in the inset in the lower part of the figure. Photo: Svein Dale

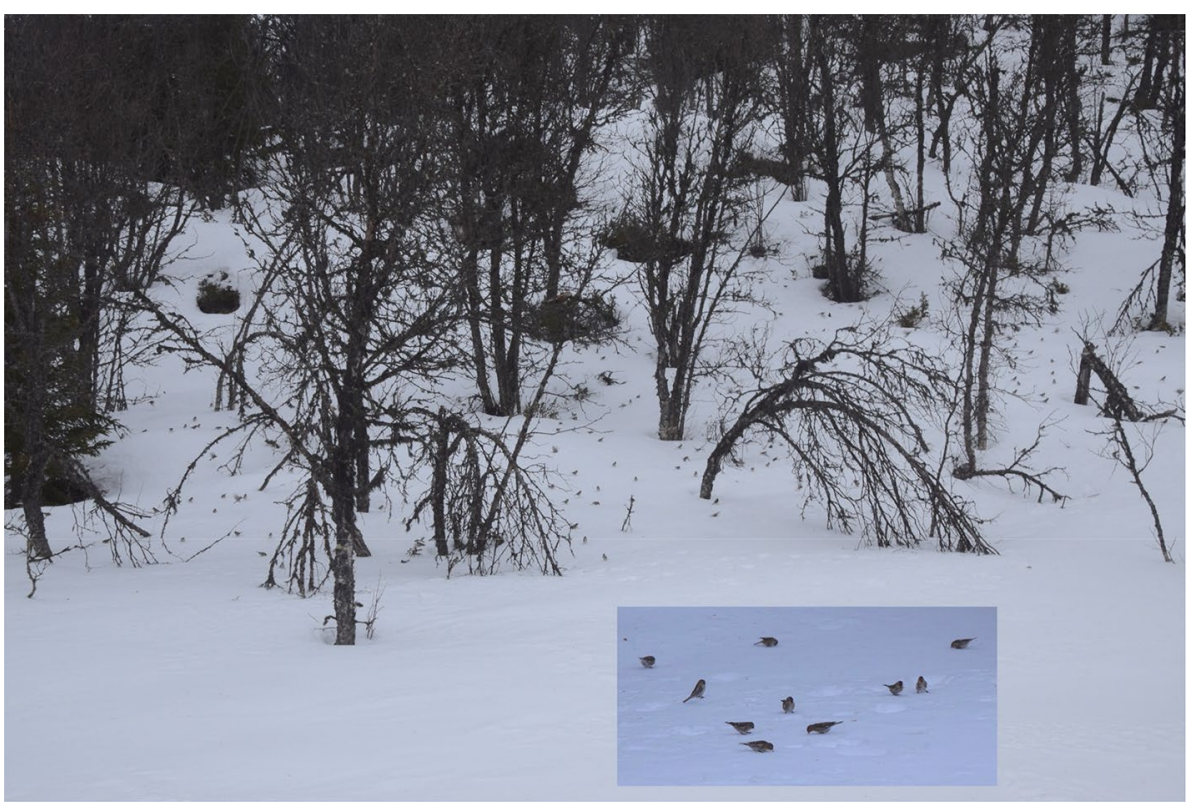

cover at least during the start of the breeding season. Snow cover may depend on elevation, latitude and longitude, and I, therefore, also tested whether snow cover had effects on redpoll abundance independent of other variables. I supplement the analyses with behavioral observations to illustrate the use of snow-covered ground by redpolls. Finally, I investigate seasonal trends in abundance and timing of breeding to assess the hypothesis that redpolls may show altitudinal migration in peak seed crop years, first breeding at lower elevation to take advantage of spruce seed crops, and then breeding for a second time at higher elevation, in subalpine birch forests (Peiponen 1957; Hogstad 1996).

\section{Methods}

\section{Study area}

During 31 March-23 June 2020, I surveyed a large number of sites in Oslo county and the Akershus region (part of Viken county) in southeastern Norway. The 191 sites included in this study had a significant proportion of forest, whereas sites with mostly wetland or farmland habitats were excluded. Sites were generally defined according to topographical and spatial features (such as hills, valleys, forest 
patches surrounded by other habitats etc.), and had areas of approximately 50-500 ha. Sites were defined previously for other purposes (see, e.g., Dale et al. 2001).

The surveyed sites were located along an elevational gradient from close to the sea level near the coast in the south and to about $800 \mathrm{~m}$ a.s.l. in the northwestern parts of the study area. Sites closest to the coast were within the nemoral zone, but most sites were located in the boreal zone dominated by coniferous trees [mainly spruce and Scots Pine (Pinus sylvestris)] interspersed with varying proportions of deciduous trees [in particular Downy Birch, to a lesser degree also Eurasian Aspen (Populus tremula), Grey Alder (Alnus incana) and Silver Birch (B. pendula)]. The total tree volume in Oslo and Akershus is dominated by spruce (60\%), pine (26\%) and birch (9\%; Tomter et al. 2001). In the northwestern part of the study area, where many study sites were located, spruce is even more dominating. Most of the boreal forests in Oslo and Akershus are production forests, so that there is a mosaic of mature forest, clear-cuts and regenerating forest.

Climatic variables are known to synchronize seed production of the main tree species found in the study area on spatial scales up to $1000 \mathrm{~km}$ (Gallego Zamorano et al. 2018). Most tree species flowered massively during spring and summer 2019, probably triggered and synchronized by an exceptionally dry and warm summer in 2018, especially in southeastern Norway (Skaland et al. 2019). Spruce had the largest cone production in recent times in southeastern parts of Norway in 2019 (Norskog 2019; Norsk Skogbruk 2019), and also in central and southern Sweden (Wennström and Almqvist 2018; Isaksson 2019). In 2019, birch pollen counts in the air in southern parts of Norway were 2.2-3.6 times higher than the average for the period 2010-2019, and 5-108 times higher than in 2018, whereas birch pollen counts were higher in 2018 than in 2019 in northern Norway (Ramfjord 2019). In Sweden, high pollen counts of birch in 2019 were in particular from western parts, including parts neighboring eastern Norway (Ekebom and Dahl 2020). Thus, synchronous masting of several tree species occurred over wide areas in Norway and Sweden, and in my study area this was obvious both at lower and higher elevations, and in all sites surveyed (personal observations).

\section{Field surveys}

Field surveys took place from sunrise until midday on days with fair weather conditions. No sites that were visited after $12.00 \mathrm{~h}$ were included, but if surveys started earlier, survey parts that took place after $12.00 \mathrm{~h}$ were included. Surveys were conducted mainly on foot or with skis, and to a smaller degree with bicycle. All birds recorded along the survey routes were included without distance limits. However, most observations of redpolls were within ca. $100 \mathrm{~m}$ from the survey routes. I recorded the approximate number of individuals seen for each site surveyed. High densities in some sites in combination with extensive display flights made exact counts impossible. During the first part of the study, all birds recorded were adults, whereas from the end of May numbers also included juveniles (see further in "Results" and "Discussion"). In most sites, birds observed were the nominate subspecies of redpoll (C.f. flammea), but lowland sites in southern parts of the study area may also hold Lesser Redpoll (C. f. cabaret, Dale et al. 2001; Lesser Redpoll was treated here as a subspecies based on the results of Ottvall et al. 2002; Marthinsen et al. 2008). Although redpolls may be more easy to see if they are on white snow cover, they were easily recorded both in areas with snow cover and in areas without snow cover because they moved frequently and were very vocal. Thus, there is no reason to believe that numbers were underestimated in areas without snow cover.

During surveys, observations of foraging and breeding behavior were made opportunistically. Observations indicated that breeding behaviors such as male display, pairs instead of flocks, short distance between pair members and interactions between males or pairs were widespread already during the earliest surveys. Thus, although in many years redpolls show migratory behavior and flocks move around well into April in the study area, this was not the case in 2020, and all observations made during the study period were regarded as representing breeding season occurrences.

Survey effort was recorded as the number of minutes spent surveying each site. For a subset of the material [23 survey days with survey routes reaching above $500 \mathrm{~m}$ a.s.l.; material covering $121.8 \mathrm{~h}$ ( $51 \%$ of total survey duration) with 5429 individuals recorded (90\% of all individuals recorded)] survey length was also calculated $(270.5 \mathrm{~km}$ for this subset of the data). For these survey routes survey time was strongly correlated with survey length $\left(r^{2}=0.83\right.$, $P<0.0001)$, and survey speed had an overall average of $2.22 \mathrm{~km} / \mathrm{h}$ (range $1.54-3.01 \mathrm{~km} / \mathrm{h}$ ).

A limited number of sites $(N=16)$ were surveyed twice to obtain data on temporal changes in number of individuals observed. However, elsewhere only the first survey of a site was included in analyses.

\section{Site variables}

Elevation, latitude and longitude were recorded from http:// www.norgeskart.no. For each site, I recorded both lower and upper elevation of the survey route, and based on those I also calculated mean elevation. Latitude and longitude were recorded in a geographical decimal format to be suitable for statistical analyses.

Data on snow depth were taken from http://www.senor ge.no. This website has been developed by the Norwegian Water Resources and Energy Directorate (NVE), the 
Norwegian Meteorological Institute and the Norwegian Mapping Authority, and provides estimates of snow depth all over Norway based on precipitation and temperature data through the winter with a $1 \mathrm{~km}$ resolution (Engeset 2016). For the study area, personal observations indicated a good fit between observed snow depths during field surveys and estimated snow depths. I used the snow depth estimated for the highest part of a site for 1 April 2020 because field observations indicated that this was the time when Common Redpolls settled in potential breeding areas, and this snow depth may, therefore, have had an impact on numbers of individuals in a site. I also used a variable for snow cover on 1 April (snow absent, i.e., snow depth $=0$, or snow present).

\section{Historical data}

To compare the magnitude of the occurrence of redpolls in 2020 with previous years, I used own field surveys conducted during April-August 1999-2019. For sites that surpassed $500 \mathrm{~m}$ a.s.l. and were located in the northwestern parts of Oslo and Akershus (Oslo, Nittedal, Nannestad, Hurdal and Eidsvoll municipalities), I retrieved the number of redpolls recorded during 149 surveys to 85 sites (1-5 surveys per site, mean 1.75). At least one survey had been conducted in each year during 1999-2019 (range 1-23, mean 7.1). Survey methods were similar to 2020, and survey effort did not differ between 1999-2019 and 2020 (36 sites surveyed both during 1999-2019 and in 2020 and with data on survey duration; mean survey duration during 1999-2019= $116 \mathrm{~min}$, range: $20-260 \mathrm{~min}$; mean survey duration in $2020=128 \mathrm{~min}$, range $20-315 \mathrm{~min}$; Wilcoxon signed-ranks test: $z=-0.74, P=0.46$ ).

\section{Statistical analyses}

To analyze which factors influenced spatial distribution of redpolls, I first conducted a zero-inflated Poisson regression of how number of individuals observed was related to site elevation, latitude and longitude. The three measures of elevation described above differed in their ability to explain number of birds observed. Lower elevation of a site had a lower $\mathrm{AIC}_{\mathrm{c}}$ value (3912.87) than mean elevation (3939.64) or upper elevation (4020.14), and was therefore used in this analysis. Survey date $(1=1$ April $)$ and survey duration (min) were included as covariates to control for time effects and survey effort.

Next, I conducted zero-inflated Poisson regressions which replaced elevation, latitude and longitude with snow depth or snow cover. Survey date and survey duration were included as covariates. Finally, full analyses including both elevation, latitude, longitude and snow depth/snow cover were conducted, with survey date and survey duration included as covariates. Although several of the explanatory variables (elevation, latitude, longitude and snow depth) were significantly intercorrelated, analyses of variance inflation factors indicated that there were no problems with multicollinearity (VIF values 1.2-3.9). Additionally, a GLM analysis of how elevation, latitude and longitude influenced snow depth was conducted, using upper elevation because snow depth was estimated for the upper parts of each site. Analyses were conducted with JMP Pro version 15.

\section{Results}

\section{Number of birds observed}

During a total of $237.9 \mathrm{~h}$ of surveys in 2020, 6022 individuals of redpolls were recorded (mean 25.3 individuals $/ \mathrm{h}$ ). The number of individuals recorded per site ranged from 0 to 800 (mean 31.5, $N=191$ sites). Surveys with high observation rates of redpolls were concentrated to higher elevation sites in the northwest of Akershus (Fig. 3; see Supplementary Information, Fig. S1 for corresponding map with absolute numbers recorded in each site). Thus, sites that reached at least $500 \mathrm{~m}$ a.s.1. had an average observation rate of 52.0 individuals/h (5342 individuals in 49 sites in $102.7 \mathrm{~h}$ ) whereas sites not surpassing $500 \mathrm{~m}$ elevation had an average observation rate of 5.0 individuals/h (680 individuals in 142 sites in $135.3 \mathrm{~h}$ ).

During 1999-2019, mean number of redpolls recorded per site was 1.1 (range 0-30; based on 149 surveys of 85 sites surpassing $500 \mathrm{~m}$ a.s.l. and located in northwestern parts of the study area). Even when biasing the sample to sites and years in which redpolls were recorded, the mean was only 4.3 individuals recorded $(N=39$ surveys of 32 sites; 4.0 individuals/h for 18 surveys of 18 sites with information on survey duration). Pairwise comparison between number of redpolls recorded in 2020 versus previous years was possible for 39 sites (survey effort was similar across years, see "Methods"). Using the highest number observed in any year between 1999 and 2019, the numbers recorded in 2020 were still more than a magnitude larger than previously recorded (Fig. 4; mean 1999-2019 $=2.6$, range: 0 -30 ; mean $2020=130.9$, range: $1-800$; Wilcoxon signed-ranks test: $z=-5.37, P<0.0001)$. This was also the case when restricting the comparison to sites and years in which redpolls were recorded during 1999-2019 ( $N=20$ sites; mean $1999-2019=5.0$, range: $1-30$; mean $2020=156.4$, range: 2-800; Wilcoxon signed-ranks test: $z=-3.77, P=0.0002$ ). The highest previous occurrence was in 2011 when an average of 13.1 individuals were recorded ( 15.3 when excluding sites with no birds recorded, $N=6$ sites remaining for comparison). The numbers recorded in 2020 in the same sites (4 
Fig. 3 Distribution and number of Common Redpolls (Carduelis flammea) recorded per hour in 191 sites in Oslo and Akershus, SE Norway, during the breeding season of 2020
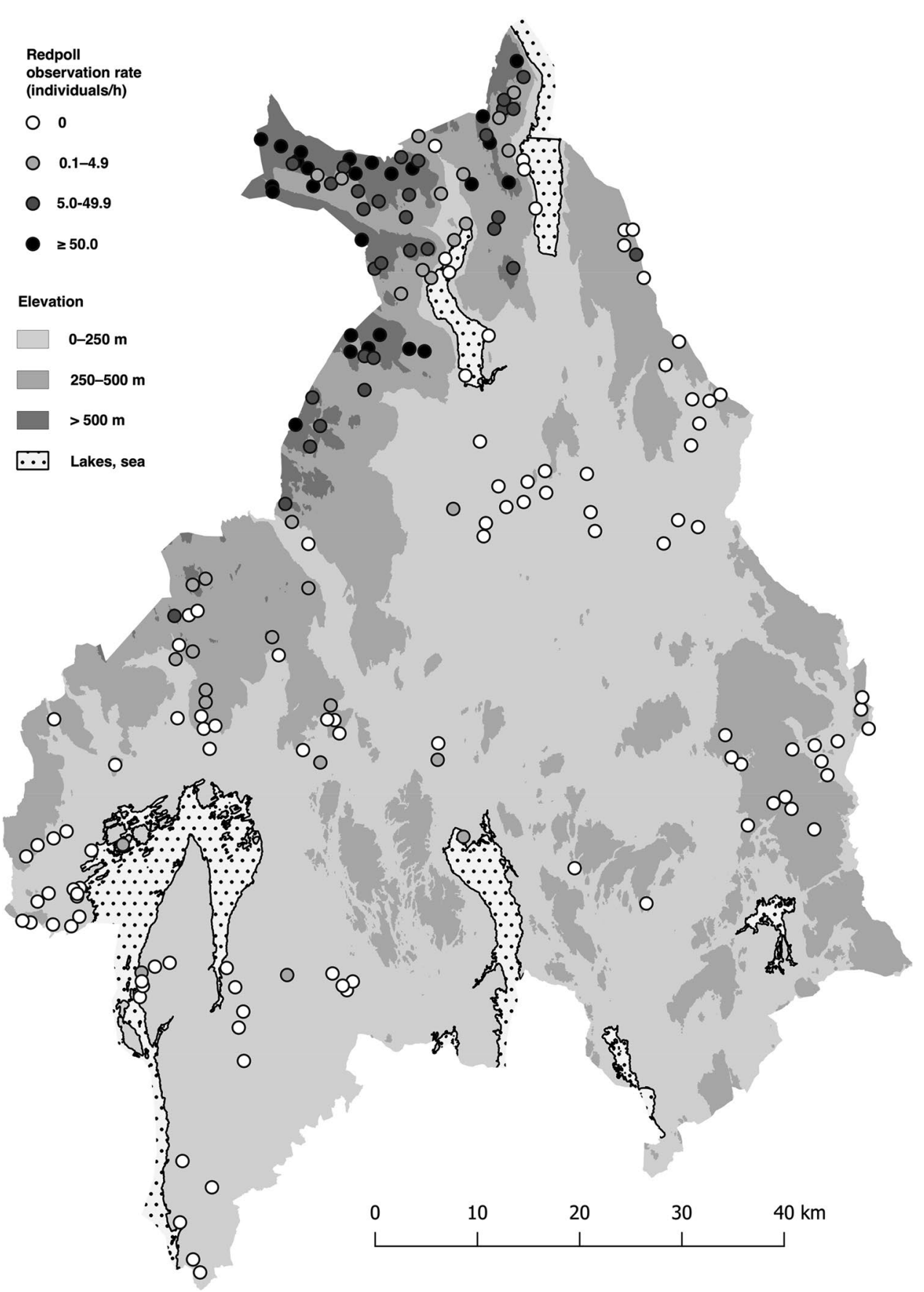

Lakes, sea sites were surveyed in both 2011 and 2020) was on average 19.1 times higher in 2020 than in 2011 (2-30 individuals recorded in 2011, 20-500 individuals recorded in 2020).

\section{Seasonal trend}

Repeated surveys of the same sites suggested that there was a trend for a decline in numbers over time during the 2020 breeding season. During the first survey of 16 sites surveyed twice, 210 individuals were observed during 5 April-12 May. During the second survey of these sites,
76 individuals were observed during 12 May-19 June (on average 43 days later), but the difference was not statistically significant (Wilcoxon signed-ranks test: $z=-1.36$, $P=0.17)$. The number of individuals observed during the two surveys were strongly correlated $\left(r_{\mathrm{s}}=0.85, N=16\right.$, $P=0.001)$. Analyses of presence/absence indicated a significant relationship so that sites with presence in the first survey generally had presence in the second survey too ( 9 out of 10 sites); whereas, sites with absence in the first survey generally had absence in the second survey (5 out of 6 sites; Fisher exact test: $P=0.008$ ). 


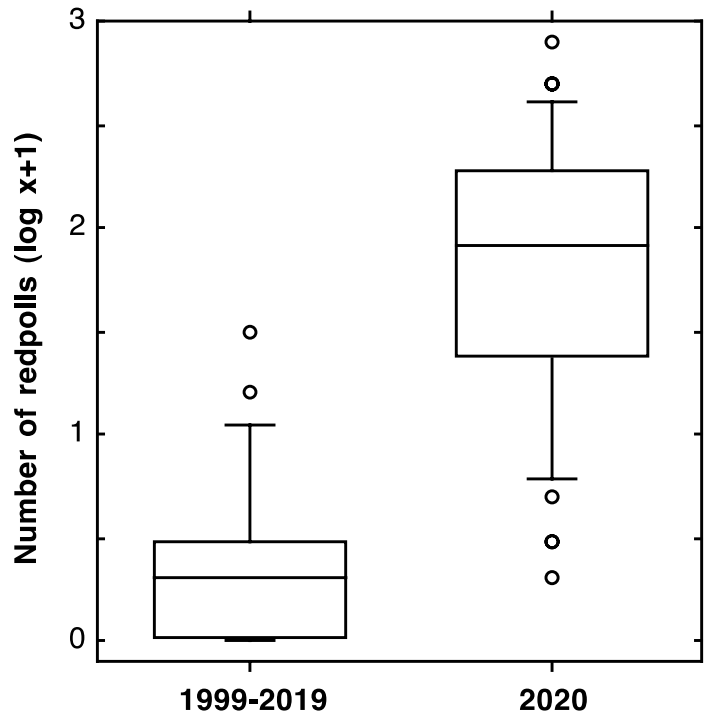

Fig. 4 Boxplots of number of Common Redpolls (Carduelis flammea) recorded in Oslo and Akershus, SE Norway, during AprilAugust 1999-2019 compared to during the breeding season of 2020. Data were from 39 sites surveyed in both time periods, and the highest number observed in any year between 1999 and 2019 was used for the comparison with 2020

\section{Elevation, latitude and longitude}

Scatterplots indicated that the number of redpoll individuals observed was related to all explanatory variables (survey date, survey duration, elevation, latitude, longitude; Fig. 5a-e). A zero-inflated Poisson regression indicated that the number of individuals observed increased with survey duration and elevation, and towards the northwest, and that numbers decreased with survey date (Table 1).

\section{Snow depth}

On 1 April, 57 of the 191 sites (30\%) had at least some snow cover. Snow depth increased with elevation and towards the west, but declined towards the north (Fig. 6, Table 2). Snow was present from about $400 \mathrm{~m}$ a.s.l. and upwards (Fig. 6).

The 57 sites with snow cover on 1 April held $96.4 \%$ of all individuals recorded (5806 out of 6022 individuals, recorded in 53 of the 57 sites). The number of redpolls recorded was positively related to snow depth (Fig. 5f). Snow depth or snow cover (only together with survey date and survey duration) had significant relationships (both $P<0.0001$ ) with number of redpolls recorded, but had larger $\mathrm{AIC}_{\mathrm{c}}$-values (5768.30 and 4871.37, respectively) than the model with elevation, latitude and longitude (Table $1 ; \mathrm{AIC}_{\mathrm{c}}=3912.87$ ).

However, a model that included snow depth and the other variables had a better fit $\left(\mathrm{AIC}_{\mathrm{c}}=3895.65\right)$ than the model without snow depth (Table 1: $\mathrm{AIC}_{\mathrm{c}}=3912.87$ ). But the best model included snow cover and the other variables
$\left(\mathrm{AIC}_{\mathrm{c}}=3349.68\right)$, with number of redpolls recorded being higher when the ground was snow-covered, and increasing with survey duration, elevation and towards the northwest, and decreasing with survey date (Table 3 ). Thus, snow cover explained data better than snow depth. Correspondingly, a model with only the 57 sites with snow cover on 1 April did not show a significant effect of snow depth on number of redpolls recorded $(P=0.73)$.

Figure 6 indicated that on 1 April snow cover was mostly absent below $400 \mathrm{~m}$ a.s.l. and mostly present above $550 \mathrm{~m}$ a.s.l. Thus, variation in snow cover occurred mostly between 400 and $550 \mathrm{~m}$ elevation $(N=51$ sites of which 49 were in northwestern parts of the study area). In this elevation zone, sites with snow cover had a higher observation rate of redpolls (mean $=38.4$ individuals $/ \mathrm{h}, N=24$ ) than sites without snow cover (mean $=7.2$ individuals $/ \mathrm{h}, N=27$; ratio snow cover $/$ no snow $=5.4 ; t=3.26, \mathrm{df}=49, P=0.0021)$. The observation rate was also higher in sites with snow cover for each $50 \mathrm{~m}$ interval in this elevation zone $(400-450 \mathrm{~m}$ : ratio $=6.8 ; 450-500 \mathrm{~m}$ : ratio $=1.8 ; 500-550 \mathrm{~m}$ : ratio $=10.6$ ).

\section{Foraging behavior}

During the first field survey included in this study, there were large quantities of spruce seeds on the snow cover (Fig. 1). During the study period, all foraging observations were of redpolls taking spruce seeds, and they foraged for seeds both in trees and on the snow. Relatively few observations of foraging on snow-free ground were made. Foraging took place on the snow as long as snow patches remained. Because of cold weather during May, snow patches were seen as late as 28 May at the higher elevations $(680 \mathrm{~m}$ a.s.l., Rognhaugen, Hurdal municipality). The last snow patches were used intensively by large numbers of redpolls, at that time including juveniles of the year. For example, on 22 May groups of 10-20 individuals foraged on snow patches with an area of only a few square meters, whereas foraging on snow-free ground was less common (550 m a.s.l., Tuvsætra, Hurdal municipality). During surveys in April and May, birds were observed foraging on snow in 33 out of 57 sites that had snow on 1 April (4 of the 57 sites had no redpolls; 15 sites were surveyed after all snow had disappeared; 5 sites had snow but foraging on snow was not observed, but these sites held only $1-10$ redpolls).

\section{Breeding behavior}

From the start of the study period and well into May, nearly all observations of redpolls suggested breeding behavior: observations were either of displaying males, pairs with pair members at short distance from each other, or interactions between males or pairs. Virtually, no observations of groups or flocks were made. Direct evidence of nesting was 

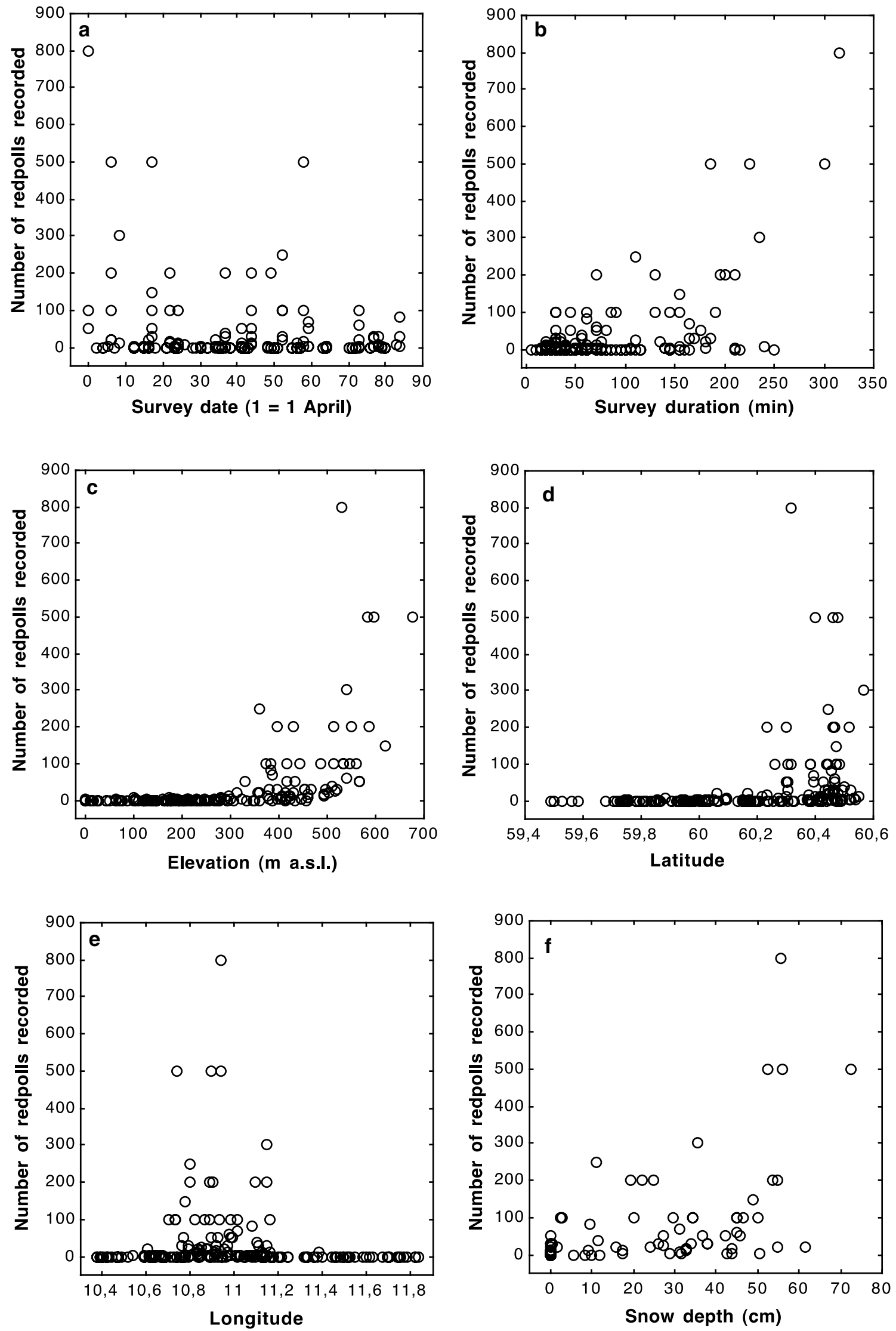
४Fig. 5 Relationships between number of Common Redpolls (Carduelis flammea) recorded in 191 sites in Oslo and Akershus, SE Norway, during the breeding season of 2020, and six explanatory variables: a date, $\mathbf{b}$ survey duration, $\mathbf{c}$ elevation (lower elevation of a site), $\mathbf{d}$ latitude, e longitude, and $\mathbf{f}$ snow depth. All relationships have $P<0.05$. Overlapping data points are not indicated, but for a-e nearly all are for number of redpolls $=0$. For $\mathbf{f}$ nearly all overlapping data points are for snow depth $=0$ and number of redpolls $=0$

not observed, although some observations suspected to be of nesting individuals were made in the end of April and beginning of May. However, fully plumaged juveniles flying together with adults in flocks and flocks consisting mainly of juveniles were seen the first time 22 May. From that date, juveniles were seen in most sites that held $\geq 10$ redpolls.

\section{Discussion}

\section{Mass occurrence in 2020}

The redpoll is generally considered an irregular breeder in small numbers in Oslo and Akershus (Dale et al. 2001). In this study, I documented a mass occurrence in 2020 with more than 6000 individuals recorded during the field work, most of them in about 50 sites above $400 \mathrm{~m}$ elevation. The total number in such areas in Oslo and Akershus must have been tens of thousands of individuals. In several sites there were literally redpolls everywhere, and for sites surpassing $500 \mathrm{~m}$ elevation the average observation rate was about 50 individuals per survey hour.

Although not a focus of the present study, redpolls constituted a large proportion of all birds recorded in many of the surveys. In sites surpassing $500 \mathrm{~m}$ a.s.l. $(N=49)$, the redpolls recorded (5342 individuals) constituted on average $31 \%$ of all bird individuals recorded. Other species exploiting the rich spruce seed crop were the Common Crossbill (Loxia curvirostra) and the Eurasian Sisikin (Spinus spinus). Both were abundant in all sites, and the Common Crossbill sometimes even more numerous than the redpoll. Common Crossbills constituted $11 \%$ of all birds recorded in the 49 sites surpassing $500 \mathrm{~m}$ a.s.1., and Eurasian Siskins 8\% (unpublished data). In years without spruce seed crops, the Common Crossbill may be completely absent from the study area. In addition, Bramblings were breeding locally in the northwestern part of the study area, and they may also have benefitted from the availability of spruce seeds. A flock of several thousand Bramblings on migration also took advantage of spruce seeds on the snow at Skreikampen (Eidsvoll municipality) on 8 April. Thus, spruce seeds boosted bird densities in these boreal forests substantially in 2020. The redpoll, Common Crossbill and Eurasian Siskin also had peak numbers on a national scale in 2020 (Norsk institutt for naturforskning 2020), likely related to high seed availability over large areas.

The mass occurrence of redpolls in 2020 was more than a magnitude greater than in any other year during 1999-2019. Data from four sites suggested that 2020 held 19 times more birds than the previous peak in 2011. I do not have quantitative data from before 1999, but I have never experienced anything like this mass occurrence during the 1980s and 1990s during visits to some parts of the study area that held many redpolls in 2020. Thus, the mass occurrence in 2020 was likely the single highest peak in redpoll numbers during the last 40 years in the study area.

The survey methods did not allow direct estimation of redpoll population density, but in the sites surpassing $500 \mathrm{~m}$ elevation, I recorded on average 23.4 individuals per $\mathrm{km}$ survey length [based on a mean of 52.0 individuals/h (see "Results"), survey speed on average $2.22 \mathrm{~km} / \mathrm{h}$ (see "Methods")]. If it is assumed that the survey route covered a band of $100 \mathrm{~m}$ on each side (see "Methods"), a crude density estimate would indicate 117 birds per $\mathrm{km}^{2}$ in the areas with highest densities. Haftorn (1998) found a similar density (149 individuals $/ \mathrm{km}^{2}$ ) in subalpine birch forest at Venabu in central Norway in a peak year (1977). Enemar et al. (1984) found a peak density of up to 180 individuals $/ \mathrm{km}^{2}$ in subalpine birch forest at Ammarsnäs in Sweden. However, other studies have found lower densities in peak years. Hogstad (1996) found that peak densities in subalpine birch forest at Budal in Trøndelag during 1966-1996 were around 60 individuals $/ \mathrm{km}^{2}$. In any case, it appears that the mass occurrence in boreal forest with abundant supply of spruce seeds in my study area in 2020 was on a scale similar to peak years in the main breeding habitat of redpolls in Scandinavia, namely subalpine birch forests.

\section{Origin of redpolls}

In the case of the Common Crossbill, it is well known that mass immigration from distant areas occurs in peak spruce masting years (Cramp and Perrins 1994). However, the redpoll is not considered to be nomadic (i.e., breeding in different areas in different years; Cramp and Perrins 1994). The mass occurrence in 2020 documented here for the Oslo and Akershus regions may also have been extending throughout eastern Norway and western Sweden due to synchronous masting of both spruce and birch in these areas (see details in "Methods"). The area with large seed crops may have been up to at least $200,000 \mathrm{~km}^{2}$, and the redpoll had a population peak when considering all regions of Norway combined (Norsk institutt for naturforskning 2020). This raises the question where all the redpolls came from.

One possibility is that redpolls were drawn to the large seed crop areas from eastern and northern Sweden and northern Norway where seed crops were low or at least 
Table 1 Zero-inflated Poisson regression of the relationships between number of Common Redpolls (Carduelis flammea) recorded in 191 sites in Oslo and Akershus during the breeding season of 2020, and elevation, latitude and longitude

\begin{tabular}{lclcl}
\hline Variable & Estimate & SE & \multicolumn{1}{l}{$\chi^{2}$} & $P$ \\
\hline Survey date & -0.0078 & 0.0006 & 169.02 & $<0.0001$ \\
Survey duration & 0.0091 & 0.0002 & 2231.4 & $<0.0001$ \\
Elevation (lower) & 0.0029 & 0.0002 & 244.6 & $<0.0001$ \\
Latitude & 2.989 & 0.164 & 333.5 & $<0.0001$ \\
Longitude & -1.614 & 0.123 & 171.7 & $<0.0001$ \\
\hline
\end{tabular}

Date and survey duration were included as covariates

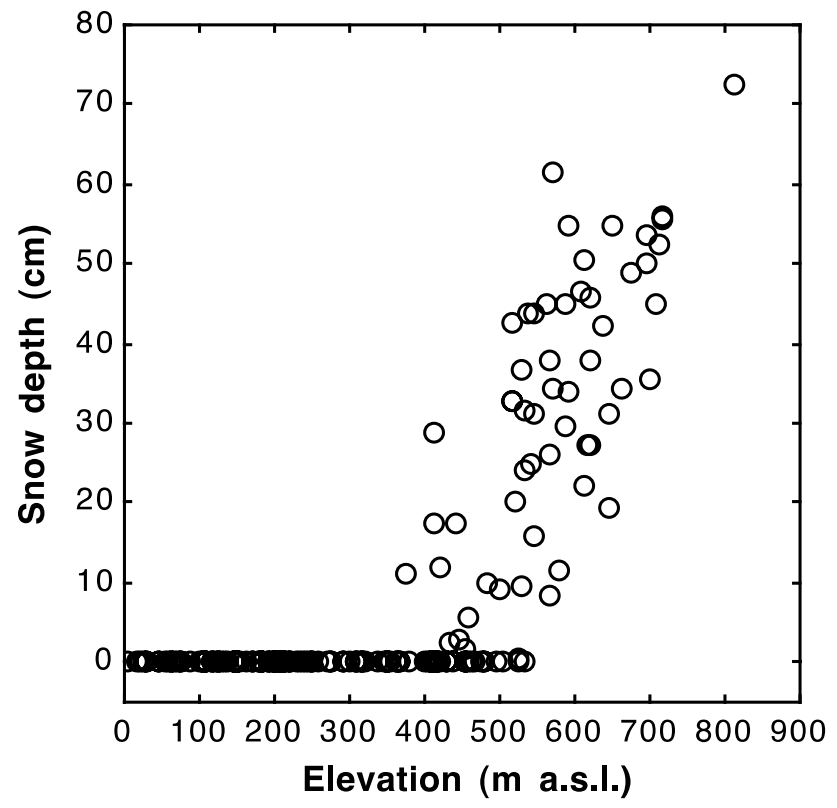

Fig. 6 Relationship between elevation (upper elevation of a site) and estimated snow depth in 191 sites in Oslo and Akershus, SE Norway, on 1 April 2020. Overlapping data points are not indicated, but nearly all are for snow depth $=0$

Table 2 GLM analysis of the relationships between snow depth on 1 April 2020 in 191 sites in Oslo and Akershus, and elevation, latitude and longitude

\begin{tabular}{lclrr}
\hline Variable & Estimate & SE & \multicolumn{1}{l}{$l$} & \multicolumn{1}{l}{$P$} \\
\hline Elevation (upper) & 0.080 & 0.006 & 13.79 & $<0.0001$ \\
Latitude & -13.02 & 4.21 & -3.09 & 0.002 \\
Longitude & -6.65 & 2.40 & -2.77 & 0.006 \\
\hline
\end{tabular}

lower than in eastern Norway and western Sweden. If so, this represents a previously undocumented large-scale redistribution of breeding redpolls. However, there is also a possibility that the indications of peak population size may have been exaggerated. According to the methodological instructions
Table 3 Zero-inflated Poisson regression of the relationships between number of Common Redpolls (Carduelis flammea) recorded in 191 sites in Oslo and Akershus during the breeding season of 2020, and elevation, latitude, longitude and snow cover

\begin{tabular}{lclcl}
\hline Variable & Estimate & SE & $\chi^{2}$ & $P$ \\
\hline Survey date & -0.0066 & 0.0006 & 122.6 & $<0.0001$ \\
Survey duration & 0.0088 & 0.0002 & 2141.14 & $<0.0001$ \\
Elevation (lower) & 0.0016 & 0.0002 & 70.05 & $<0.0001$ \\
Latitude & 3.390 & 0.163 & 431.3 & $<0.0001$ \\
Longitude & -1.292 & 0.123 & 110.4 & $<0.0001$ \\
Snow cover (yes/no) & 1.612 & 0.082 & 384.2 & $<0.0001$ \\
\hline
\end{tabular}

Date and survey duration were included as covariates

to surveyors in the Norwegian population monitoring project, surveys should be done during the period 20 May-10 July, adapted to the progression of the spring (Norsk institutt for naturforskning 2020). Thus, it is conceivable that surveys may have overestimated population size if redpolls have altitudinal migration between one brood in the lowlands and one brood in mountain forest (see below for evidence of this), and that the mass occurrence in lowlands was based on birds that normally breed in subalpine birch forest in southern Norway. In conclusion, the origin of birds in this mass occurrence is uncertain, either immigrants from distant areas, or double-brooding of the south Norwegian population.

\section{Importance of snow cover}

The analyses indicated that numbers of redpolls increased with elevation and towards the northwest. These factors could be directly related to how redpolls choose breeding sites because elevation and closeness to the main mountain range in southern Norway (northwest of the study area) could affect forest structure, tree species composition and other vegetational and climatic factors influencing habitat selection. However, I found that snow depth also increased with elevation and therefore peaked in the northwestern parts of the study area. Snow depth and snow cover alone explained a large proportion of the variation in redpoll numbers, and also had independent effects in models that combined snow depth or snow cover with elevation, latitude and longitude. Thus, I found that the 57 sites with snow cover on 1 April (30\% of all sites) held $96.4 \%$ of all individuals recorded, and that in the elevation zone that had sites both with and without snow cover in early April, sites with snow cover had more than five times higher observation rate of redpolls than sites without snow cover. These findings suggest that breeding site selection of redpolls may have been directly linked to the presence of snow on the ground, and not simply an effect of elevation through, e.g., lower temperatures. 
The hypothesis that snow cover influences habitat selection of redpolls due to facilitation of food access was supported by widespread observations of redpolls foraging for spruce seeds on the snow cover as long as snow was present. Due to early breeding (see below) redpolls may have had easy access to food during a large part of the breeding season in many sites at higher elevations. Foraging on snow by redpolls is probably common, but has previously been reported only a few times. Notably, Hogstad (1996) reported that birch seeds on the snow were an important food source for redpolls after arrival in spring to the breeding areas in subalpine birch forest. He also reported that foraging on snow is probably risky because he saw both Hawk Owl (Surnia ulula) and Eurasian Magpie (Pica pica) attacking redpolls on the snow, indicating that foraging on snow must be energetically highly profitable to balance the increased predation risk. Hawk Owls detect voles moving on top of the snow cover at much longer distance than voles moving on snow-free ground (Sonerud 1992), so redpolls are likely to be exposed to a higher predation risk when foraging on snow than when foraging on snow-free ground.

The results suggested that much of the effect of snow was due to a contrast between small numbers of redpolls in sites without snow cover on 1 April, and large numbers in sites with snow cover. This raises the question whether redpolls simply look for sites with snow cover, or if snow depth also plays a part in their habitat selection. This may depend on whether redpolls have been selected to use a larger snow depth as a proxy for a longer time period with snow cover and thereby better food access for a longer time. A related question is whether redpolls actually can assess snow depth directly. In open areas with continuous snow cover this may be difficult, but in forested areas, in particular with some ruggedness, snow depth on, e.g., boulders, treefalls and slopes may be directly visible. Furthermore, during early April some melting has usually already taken place, so that at least small bare patches under trees and in south-facing slopes may provide additional information. The larger the snow depth, the fewer bare patches will be present. Thus, snow depth in combination with the proportion of the area that is snow covered may be useful cues available to redpolls when choosing a breeding site.

\section{Seasonal trend and breeding patterns}

Sites that were surveyed twice showed a trend that numbers decreased over time, although the decline was not statistically significant. However, all GLM analyses indicated a small, but significant decline in number of individuals recorded over time. In addition, from the end of May, the number of individuals recorded also included juveniles, so that the number of adults during that period was even lower. One possibility could be that some of the birds recorded during April were still on spring migration and did not settle to breed. However, as argued in "Methods", the behavior of the birds generally indicated that the birds were preparing for breeding. Furthermore, large number of redpolls recorded continued well into May, long after the time when spring migration of redpolls in normal years has ended in the study area. Thus, I conclude that the results were not affected by birds still on spring migration during the first part of the study period.

Another possibility is that some birds left the study area during May and June due to failed breeding, or even that they left after successful breeding. In the latter case, it has been suggested that redpolls may have two clutches in large seed crop years, first breeding at lower elevation and then moving to subalpine birch forest for a second breeding (Peiponen 1957; Hogstad 1996; see also Troy and Shields 1979). Such altitudinal breeding migration could be a strategy to track optimal foraging conditions related to snow cover. In subalpine birch forest in southern Norway, snow may still be present on the ground well into June in some years, so that also the second breeding event could benefit from easy access to seeds on the snow.

In the study area, independent juvenile redpolls were first seen 22 May. I assume that these juveniles must have fledged at least 5-10 days earlier. The nestling period of redpolls in Norway is 12 days, and the incubation period lasts 11 days and starts when the second or third egg is laid (Haftorn 1971). This indicates that egg-laying in the study area may have started around 20 April. Nest building may then have begun around the middle of April. This corresponds well with field observations indicating the onset of breeding season behavior (pair formation etc.) already in early April, and literature information that early nesting in Norway may sometimes occur already in April (Haftorn 1971). Importantly, early nesting with independent juveniles in the last half of May may give adults the possibility to have a second clutch, possibly after an altitudinal migration to track snowcovered ground, and thereby explain the seasonal decline in numbers recorded in the study area.

\section{Causes of mass occurrence of redpolls: importance of masting}

I suggest that the mass occurrence of redpolls in 2020 was due to a unique combination of exceptionally large seed crops of two tree species coinciding in the same year, probably synchronized by a record summer drought preceding masting. The summer of 2018 was exceptionally dry and warm, especially in southeastern Norway (Skaland et al. 2019). Drought and heat are thought to trigger masting of many tree species (e.g., Piovesan and Adams 2005; Gallego Zamorano et al. 2018), and in the spring of 2019 nearly all tree species in the study area, possibly with the 
exception of Scots pine, had a peak masting year (personal observations, see also references in "Methods").

Based on own observations preceding the present study, redpolls were seen foraging on seeds of birch during the autumn of 2019 and until at least February 2020. My first observation of foraging on spruce seeds was made 25 January 2020. However, seed release from spruce cones started in particular in February-March (Fig. 2), and during the first field survey included in this study, there were large quantities of spruce seeds on the snow cover (Fig. 1). During the study period, all foraging observations were of redpolls taking spruce seeds. Thus, the masting produced large amounts of food both for overwintering (birch seeds) and for breeding (spruce seeds). The masting of both tree species was large both in the lowlands and at higher elevation. However, the distribution of snow cover during early April may have acted as a cue for redpolls to settle in higher elevation spruce forest, through facilitation of access to the spruce seeds.

\section{Climate change and dynamics of boreal forest trees and seed-eaters}

This study indicated that snow cover may be an important part of habitat selection of redpolls. Snow cover may also benefit other seed-eaters such as, e.g., the Brambling. Climate projections forecast a substantial decrease in snow cover (e.g., Brown and Mote 2009; Callaghan 2011b). Loss of snow cover may therefore lead to altered ecosystem dynamics. Reduced seed predation from seed-eating birds may lead to more food available to other seed predators such as rodents, and thereby affect the population dynamics of other cyclic animal species. Yet, it is possible that total seed predation may decline and lead to higher recruitment rates of masting tree species which may over time change forest structure both in terms of tree species composition and tree density. On the other hand, although warmer climate may lead to less snow cover, higher temperatures may also cause larger or more frequent masting events (Gallego Zamorano et al. 2018) so that the overall effects on redpolls and other seed-eaters are difficult to predict. Thus, climate change is likely to lead to complex ecosystem changes in areas where snow cover may disappear.

Supplementary Information The online version contains supplementary material available at https://doi.org/10.1007/s10336-021-01912-x.

Acknowledgements I thank Roar Økseter for help with producing the map, and Geir A. Sonerud and two anonymous referees for comments on the manuscript.
Funding Open access funding provided by Norwegian University of Life Sciences.

Availability of data Data are available from the author on request.

\section{Declarations}

Conflict of interest The author has no conflict of interest to declare.

Open Access This article is licensed under a Creative Commons Attribution 4.0 International License, which permits use, sharing, adaptation, distribution and reproduction in any medium or format, as long as you give appropriate credit to the original author(s) and the source, provide a link to the Creative Commons licence, and indicate if changes were made. The images or other third party material in this article are included in the article's Creative Commons licence, unless indicated otherwise in a credit line to the material. If material is not included in the article's Creative Commons licence and your intended use is not permitted by statutory regulation or exceeds the permitted use, you will need to obtain permission directly from the copyright holder. To view a copy of this licence, visit http://creativecommons.org/licenses/by/4.0/.

\section{References}

Antor RJ (1995) The importance of arthropod fallout on snow patches for the foraging of high-alpine birds. J Avain Biol 26:81-85

Bilodeau F, Gauthier G, Berteaux D (2013) Effect of snow cover on the vulnerability of lemmings to mammalian predators in the Canadian Arctic. J Mammol 94:813-819

Boelman NT et al (2019) Integrating snow science and wildlife ecology in Arctic-boreal North America. Environ Res Lett 14:010401

Brown RD, Mote PW (2009) The response of Northern Hemisphere snow cover to a changing climate. J Clim 22:2124-2145

Callaghan TV et al (2011a) Multiple effects of changes in Arctic snow cover. Ambio 40:32-45

Callaghan TV et al (2011b) The changing face of Arctic snow cover: a synthesis of observed and projected changes. Ambio 40:17-31

Cheveau M, Drapeau P, Imbeau L, Bergeron Y (2004) Owl winter irruptions as an indicator of small mammal population cycles in the boreal forest of eastern North America. Oikos 107:190-198

Cramp S, Perrins CM (1994) The birds of the Western Palearctic. Volume VIII. Crows to finches. Oxford University Press, Oxford

Dale S, Andersen GS, Eie K, Bergan M, Stensland P (2001) Guide til fuglelivet i Oslo og Akershus. Norsk Ornitologisk Forening, Oslo og Akershus

Ekebom A, Dahl Å (2020) Pollensäsongen 2019 - sammanställning av pollenförekomsten i Sverige. Naturhistoriska riksmuseet and Göteborgs Universitet, Göteborg

Enemar A, Nilsson L, Sjöstrand B (1984) The composition and dynamics of the passerine bird community in a subalpine birch forest, Swedish Lapland A 20-year study. Ann Zool Fenn 21:321-338

Engeset R (2016) Hvordan lages vær- og snødata for seNorge.no og XGEO.no? https://www.nve.no/Media/4813/weatherandsnowd ata_v2_no.pdf. Accessed 15 Dec 2020

Gallego Zamorano J, Hokkanen T, Lehikoinen A (2018) Climatedriven synchrony in seed production of masting deciduous and conifer tree species. J Plant Ecol 11:180-188

Haftorn S (1971) Norges fugler. Universitetsforlaget, Oslo

Haftorn S (1998) Breeding bird population in a subalpine birch forest in central Norway, with notes on the winter feeding strategy of Carduelis flammea. Fauna Norv Ser C, Cinclus 21:75-85 
Haldås S (1971) Rekordartet lavlandshekking hos gråsisik i NordTrøndelag i 1971. Sterna 10:279-283

Hogstad O (1996) Gråsisiken - en liten nomade. Vår Fuglefauna 19:149-155

Isaksson S (2019) Skogen tror den ska dö - här är anledningen till alla frön och kottar. https://sverigesradio.se/artikel/7224699. Accessed $17 \mathrm{Feb} 2021$

Jacobsen BV, Sonerud GA (1993) Synchronous switch in diet and hunting habitat as a response to disappearance of snow cover in Tengmalm's owl Aegolius funereus. Ornis Fenn 70:78-88

Jenni L (1987) Mass concentrations of Bramblings Fringilla montifringilla in Europe 1900-1983: their dependence upon beech mast and the effect of snow-cover. Ornis Scand 18:84-94

Koenig WD, Knops JMH (2001) Seed-crop size and eruptions of North American boreal seed-eating birds. J Anim Ecol 70:609-620

Lifjeld JT, Bjerke BA (1996) Evidence for assortative pairing by the cabaret and flammea subspecies of the Common Redpoll Carduelis flammea in SE Norway. Fauna Norv Ser C, Cinclus 19:1-8

Marthinsen G, Wennerberg L, Lifjeld JT (2008) Low support for separate species within the redpoll complex (Carduelis flammeahornemanni-cabaret) from analyses of mtDNA and microsatellite markers. Mol Phylogenet Evol 47:1005-1017

Melin M, Mehtätalo L, Helle P, Ikonen K, Packalen T (2020) Decline of the boreal willow grouse (Lagopus lagopus) has been accelerated by more frequent snow-free springs. Sci Rep 10:6987

Newton I (1972) Finches. Collins, London

Newton I (1998) Population limitation in birds. Academic Press, San Diego

Newton I (2006) Advances in the study of irruptive migration. Ardea 94:433-460

Norsk institutt for naturforskning (2020) Hekkefuglovervåking TOV-E. Resultater 2006-2020. https://tov-e.nina.no/hekkefugl. Accessed 15 Dec 2020

Norskog (2019) Beste frøår i nyere tid: har samlet frø til 500 millioner skogstrær. https://norskog.no/nytt-fra-andre-medier-forsiden-ogegen-side/beste-konglear-i-nyere-tid-har-samlet-fro-til-500-milli oner-skogstraer/. Accessed 9 Feb 2021

Norsk Skogbruk (2019) Utsikter til rik blomstring på gran. https:// norsk-skogbruk.no/aktuelt/utsikter-til-rik-blomstring-pa-gran/. Accessed 9 Feb 2021

Nybo JO, Sonerud GA (1990) Seasonal changes in diet of Hawk Owls Surnia ulula: importance of snow cover. Ornis Fenn 67:45-51

Ottvall R, Bensch S, Walinder G, Lifjeld JT (2002) No evidence of genetic differentiation between lesser redpolls Carduelis flammea cabaret and common redpolls Carduelis f. flammea. Avian Sci $2: 237-244$
Peiponen VA (1957) Wechselt der Birkenzeisig, Carduelis flammea (L.), sein Brutgebiet während des Sommers? Ornis Fenn 34:41-64

Piovesan G, Adams JM (2005) The evolutionary ecology of masting: does the environmental prediction hypothesis also have a role in mesic temperate forests? Ecol Res 20:739-743

Ramfjord H (2019) Statistikk - pollenregistreringer 2004-2019. https:// www.naaf.no/fokusomrader/allergi-og-overfolsomhet/pollenalle rgi/statistikk---pollenregistreringer-2004---2015/. Accessed 9 Feb 2021

Resano-Mayor J (2019) Snow cover phenology is the main driver of foraging habitat selection for a high-alpine passerine during breeding: implications for species persistence in the face of climate change. Biodivers Conserv 28:2669-2685

Rosvold J (2016) Perennial ice and snow-covered land as important ecosystems for birds and mammals. J Biogeogr 43:3-12

Skaland RG et al (2019) Tørkesommeren 2018. METinfo, report 14/2019. Norwegian Meteorological Institute, Oslo

Slatyer RA, Arnold PA (2020) A systematic quantitative review of ecological responses to variation in seasonal snow cover. https:// ecoevorxiv.org/4ce37/. Accessed 15 Dec 2020

Sonerud GA (1986) Effect of snow cover on seasonal changes in diet, habitat, and regional distribution of raptors that prey on small mammals in boreal zones of Fennoscandia. Hol Ecol 9:33-47

Sonerud GA (1992) Search tactics of a pause-travel predator: adaptive adjustments of perching times and move distances by hawk owls (Surnia ulula). Behav Ecol Sociobiol 30:207-217

Sundell J, Huitu O, Henttonen H, Kaikusalo A, Korpimäki E, Pietiäinen H, Saurola P, Hanski I (2004) Large-scale spatial dynamics of vole populations in Finland revealed by the breeding success of vole-eating avian predators. J Anim Ecol 73:167-178

Tomter SM, Eriksen E, Aalde H (2001) Statistikk over skogforhold ogressurser i Akershus og Oslo. Landsskogtakseringen 1995-1999. Norsk institutt for jord- og skogkartlegging, ̊̊s

Troy DM, Shields GF (1979) Multiple nesting attempts by Alaskan redpolls. Condor 81:96-97

Wennström U, Almqvist C (2018) Kottprognos 2018. https://www. skogforsk.se/kunskap/kunskapsbanken/2018/kottprognos-2018/. Accessed 17 Feb 2021

Publisher's Note Springer Nature remains neutral with regard to jurisdictional claims in published maps and institutional affiliations. 